\title{
Resilience and death: the nursing professional in the care of children and adolescents with life-limiting illnesses
}

Rosilene Aparecida dos Santos ${ }^{1}$

Martha Cristina Nunes Moreira ${ }^{2}$

${ }^{1}$ Unidade de Internação Pediátrica, Instituto Nacional de Saúde da Mulher, da Criança e do Adolescente (IFF), Fiocruz. Av. Rui Barbosa 716, Flamengo. 22250-020 Rio de Janeiro RJ Brasil.

rosilene@iff.fiocruz.br

${ }^{2}$ Programa Saúde \& Brincar, Departamento de Pediatria, IFF, Fiocruz.

\begin{abstract}
The purpose of this article is to analyze the resilience of the nursing staff in providing care for children and adolescents with chronic diseases, including coping with their deaths. The participants of this qualitative research were nursing professionals working in the pediatric ward of a hospital in the city of Rio de Janeiro, Brazil. The data collection was obtained by applying the resilience scale, by returning the scales in groups, and by semi-structured interviews. The relationship between professional resilience and coping with the process of children and adolescent's deaths stood out in the analysis based on data obtained from group and individual interviews. The care given to children and adolescents with life-limiting illnesses triggers resilience-related answers concerning alternatives that oscillate between individual reactions (religious and psychological support), and the search for an incipient collective support based on personal relationships. This study points out that this subject must be strategically handled to train this professional, who must be able to rely on support from the collective environment, presumed within the professional health care training and in the management of humanization at the hospital.

Key words Resilience, Chronic disease, Death, Child, Adolescent, Nursing
\end{abstract}




\section{Introduction}

The process or living and dying and the health care professional practices related to it are objects of works in epidemiology, history, and anthropology fields ${ }^{1-5}$. These works guide us in the discussion and understanding of a hospitalization scenario with children and adolescents facing chronic diseases, within a dialog between care and death. Although there is much discussion, the care provided to the health/illness process is still perceived as an enigma for health care professionals when the outcome is death or life limitation.

In the Middle Age, end of life was a natural process and the sick one remained in his or her family environment until death. The death causes were usually a result from infectious diseases. However, in the 20th century, the progress made by medicine introduces a new perception of death as it becomes institutionalized with the concern focused on human longevity and economic and capitalist interests. Thus, death becomes to be part of the hospital setting, but health care professionals are not yet prepared to handle such scenario ${ }^{6}$. Although death is a part of the daily lives of nursing professionals, they show difficulties in providing care to patients undergoing dying process. The responsibility for the care seems to be inherent to the desire to cure, generating conflict and suffering for such professional". The professional still has "to manage the expression of emotions of all those involved in the dying process, such as of the patients, families, and of the health care staff itself".

During a research conducted with a nursing staff of a pediatric ward in a hospital of reference located in the city of Rio de Janeiro, we were surprised by the association between resilience discussion and care provided to children and adolescents with chronic diseases ${ }^{9}$. The discussion on "managing" death situations stood out in this analysis, becoming then object of analysis in this article, associated to the nursing staff process of building resilience.

The word resilience, etymologically speaking, means to be elastic. It is a term commonly associated to physics and mechanics as "quality of the material resistance to shock, to tension, to pressure that enables it to come back to its initial shape or position"10.

In the psychology field, resilience is understood as an individual feature, and to be resilient means to recover, move on after a disease, trauma or a stressful situation. It means to overcome life crisis and it implies that the traumatized one must overcome and recompose himself. It is the ability to evolve, to keep focusing in the future regardless the destabilizing events, hard living conditions, and sometimes severe trauma. It is the universal human ability to cope with crisis and to overcome it, to learn or even to change with life's inevitable adversities and to become stronger after overcoming the problem ${ }^{11}$.

Resilience is a skill that every human being has, at some level. It is a resource that is partially inherent but also learned along the time, once resilience, according to Cyrulnik ${ }^{12}$, "is weaved" throughout the life cycle. Resilience can grow with external situations and conditions and can be promoted with the support of people or institutions ${ }^{11}$.

The professional resilience is understood as the ability to face difficulties developed in the care to life and death process resulted from chronic illnesses. They are skills generated from the contact with those they provide care, from the beliefs and values of the professional, built along face to face relationships, generating meanings that may or may not be linked to actions within reality.

This study strives to contribute to the collective health field and to the association with other studies that explore the meanings of death and of its process within the collective health scope, in children and adolescents with chronic diseases. The difference comes from the association of this topic to the study on the nursing professional resilience within the health/disease/care circuit of children and adolescents with health chronic conditions. Moreover, it is relevant to associate this discussion with an epidemiological scenario in which the health chronic conditions, particularly the rare diseases, genetic based ones, such as syndromes, which can abbreviate life, stand out in the morbidity and mortality profile of children and adolescents ${ }^{13-15}$. This article strives to contribute with the denaturalization of the idea that suffering/death are part of the health care work dynamics ${ }^{16}$.

\section{Material and methods}

This article is part of a larger research, approved by the IFF/Fiocruz Ethics Research Committee, based on the investigation of meanings in building resilience concerning nursing professionals taking care of children and adolescents with chronic diseases. The original research counted on a first quantitative stage focused on the ap- 
plication of the Resilience Scale ${ }^{17}$. This article is composed of selected quantitative analysis generated from the second stage, which focused on the association of individual and group interviews.

The subjects of the research were 20 nursing professionals working in two pediatric wards of a mid and high complexity hospital, located in the city of Rio de Janeiro, Brazil. Many of the situations are related to chronic diseases complications. The names of the subjects are fictitious to preserve their anonymity. This professional category was chosen as they hold features focused on the proximity and intensity of the contact and care provided to patients and families. Moreover, their work involve aspects toward the welcoming, approach, interaction, management, and health education, and they represent a numerical and intervention centrality in the health care during hospitalization.

In the first stage, a tool called "Resilience Scale" ${ }^{17}$ was applied on 56 subjects to identify those who had high scores, who were more resilient. This criterion was used to select the subjects who were going to be interviewed in the second stage. The study selected 37 subjects for the individual interviews. After conducting 20 semi-structured interviews, the theoretical saturation level was reached for pre-categories or new categories ${ }^{18}$. The technical analysis of the material was based on the adaptation of Bardin's context analysis ${ }^{19}$. The study selected themes with meanings related to the analytical object, giving priority to structures of relevance and values. The data theoretical analysis was based on the symbolic interactionism by the draft of the techniques and after by interpretation of the subjects' experiences. The value given to everyday human actions and interactions provides privilege to face to face relationships and events often mediated by attribution of status or stigma ${ }^{20-22}$.

\section{Results and discussion}

\section{The dying and living process in pediatric care}

The professional care provided to children and adolescents with chronic diseases is based in an investment in the quality of life and management of a clinical condition without cure. The chronic disease, culturally speaking, does not seem to match the image of vitality and future development associated with childhood and adolescence. The chronic disease in the life of this segment may often represent that growing up and developing approximates them to death and to the symbolic marks related to it. These marks mediate the face to face relationships and interactions in a relational environment mediated by body marks, physical limitations, coping with acute symptoms of chronic diseases, demarcating stigmas ${ }^{22}$.

Rodrigues, concerning the meaning of death of adults and its difference regarding the process in children, states:

Death of an adult person usually means pain and loneness for those who stay: a real sore that endangers social life. It is different, and lighter in general, the reaction that a death of a child has on the collective conscious. In fact, the community has invested a little more than hope on them. Its mark could not be attributed to them soon enough. It does not see itself on them, so it does not really feel the pain. It is regarded as a smaller death, as a smaller infra-social phenomenon to preserve the expression ${ }^{5}$.

When the author compares death of adults with of children, he highlights the less remarkable feature to death of the latter, attributing a lighter reaction to their death. However, the author's analysis marked by an externality to the pediatric care field, places him in a line of thought of which position is associated with the ideals of a productive insertion of the child in an extended history; thus, devaluing the acknowledgment of the child as an individual staying in the present, and also the subject of a story, in a socially constructed place.

The dialog with such perspective leads to the deconstruction of the adult centered position and we acknowledge that the course of life, when interrupted during adolescence, triggers the extinction of a relationship and of a life that were shared with intensity, even if that means living few years: The death of $L$. (an adolescent) had great impact on me, once I took care of her since she was little, I think she was 5 or 6 when she got here. We became very close to each other. She used to say that I was her mother and I that she was my daughter. (Felícia)

The care provided to children and adolescents requires from the professional the development of abilities that contribute to safety, bond, and building trust. In the previous passage, it is worth to analyze the association between the temporality that marks the care given to a child with chronic disease, through 2 perspectives: 1) of an extended professional care time; 2) of a time marked by the bond, perceived as the care 
given to one's child, similar to a mother and daughter relationship.

Based on the particularities of these clients, it is applicable to use the perspective of mother and child in some observations. Winnicott points out the influence of the environment on the child's growth and development, emphasizing the importance of: "get to know" the child, to have an intense and stimulant personal relation with them, to provide a live and human stability during the care so he or she could feel safe and grow up and develop properly $y^{23}$. The environment concerns not only the physical but also the relational one, which includes the interaction between a child and an adult of reference, and the meanings built by the looks, oral language, gestures, and body language.

According to several authors ${ }^{13-15}$, the perspective of chronic disease does not come up as a prerogative of the life cycles of which adults belong. The epidemiological transition, a result from several factors resulting from alterations in health and social indicators, contributes for a "new pediatrics" ${ }^{14}$. This "new pediatrics" is composed by the contingent of children and adolescents with chronic diseases and that depend on technology, who spend their lives experiencing neurological episodes resulting from perinatal events and that are part of a segment born with genetic syndromes and rare diseases. The relation with this segment calls for the need to assign the health professional care another meaning: It was all right in the beginning [before the hospital pediatrics went through a change], but after it became harsher, there were children who used to spend three, four years with $u s$, without a mother, as they did not have anyone at the time... (Beija-flor)

The demarcation of a temporality, a window, between now and yesterday, is associated with the meaning of chronicity in pediatric care profile. This association is linked to the change that took place concerning children and adolescent's rights during their hospitalization, which is the presence of someone with them, the assurance of rooming-in care instituted by the Child and Adolescent Statute (ECA). Moreover, the extended hospitalization time due to the impossibility of clinical and social discharge, often leads the professional to do a longitudinal follow up on the growth and development of infants and children in an environment not imagined at first: the hospital.

Even when the clinical conditions of these patients restrain their oral communication, there are communication approaches based on affection, creativity, and involvement: I like what I do, but I am a little fed up, tired, I am thinking about changing... because this situation we are living in is very consuming and it is going this way, do you understand... after all these years, I am very tired of this type of patient, once you do not see a response... you try, try, try and do not see a positive reaction, the reaction is he dying. (Girassol)

Once the everyday human interactions that take place in this scenario are not much discussed and do not have a place for collective discussion, they end up being associated with emotional and physical consuming processes. The analysis of the interviews enabled to identify how much the affective approaching was associated with the interpretation of a greater suffering facing instabilities and experiences of limitation of life.

Moreover, the interpretation of the child and adolescent as human beings projected for the future. This adult-centered, socially shared view, conflicts with the reality of providing care to a segment of children and adolescents whose diseases can interrupt their life projects and bonds. The professionals are trained to perform a job that, at first, would invest in life, health, and future projects, but facing the chronic disease perspective, needs another meaning. Some of the professionals who were interviewed talked about a broader and accurate way of how to break this relational process, which diverges from other point of views that justify the mechanical act of taking care of the patients and to not get involved as a strategy to protect themselves from suffering ${ }^{24,25}$.

Literature points out that health care professionals, based on the daily technical visits, many times get discouraged toward children and adolescents that seem to be close to death. The behavior of avoiding eye contact and impersonal dialogs toward this patient can be understood as: 1) Self-protective action ${ }^{22}$;2) A behavior contrary to the resilience building process as it is not characterized as a coping action.

Concerning the distress generated by the meaning assigned to the care provided to children and adolescents with chronic diseases, this study registered the care practice density, which along the years may lead the professional to become burnout and distressed, influencing on his or her life and on actions beyond the work environment. The difficulty to cope with death has resulted in innumerable problems that affect the health care public and private systems, mainly when it concerns occupational diseases in professionals ${ }^{26}$.

Some interpretations delimit a field of impossibilities for the professional practice and 
competence, taking in account a pediatric care profile in a chronic disease environment: Here... you must have emotional balance, you have to cope with this type of client, children that have not life perspective, you know they will die, that they will suffer all the time, once all or most of them do not have a perspective, right? (Rosa)

The greatest challenge you face is to see these chronically ill children and know you can do nothing for them. The greatest challenge is to arrive here every day and see children suffering, going through aspiration, manual resuscitator, inhaling puffs, and next week the same thing [...]. You have to deal with the suffering of the same children all the time, knowing that neither the doctors nor nurses can do something to improve their conditions. They are chronically ill, unfortunately. They stop and come back, and there is not much else to hurt because they are already hurt anyway. (Antúrio)

The focus in this scenario is the care and not the cure; however, the work involving illness and death, during many years, places the individual in a fragile position and/or vulnerability of his or her basic care skills. The pointed out reality is compatible with the statement of Santos and Bueno $^{27}$ : the professional my get ill, resulting from the emotional distress faced by stressful experiences accumulated along the time of certain work activity ${ }^{27}$.

The analysis of the association and the importance given between the patients' chronicle profile and the permanent suffering nature, of lesion and impossibilities, points out that these professional show a challenging and hopeless profile, interpreting it as something impossible to be changed and generating helplessness feelings. Thus, this study claims as urgent the matters such as: what are the consequences of these findings to the construction of resilience by these professionals? Concerning the health care actions, the symbolic mediation based on the lack of hope and acknowledgment of helplessness may lead to a colder, less skillful professional.

This analysis on resilience infers that the statements given are interpretation of a reality, based on lack of investments and absence of technical skills, and they do not necessarily relate to processional care practices. The level of the interpretation is object of new meanings, from the contact with each specific situation.

The children or adolescents' reactive or little active clinical condition may lead the profession- als to create meanings based on interpretations that may result in demotivation: You go to the pediatric ward and what do you see? Chronic... chronic, few of them can interact... it is a work for nursing professionals, a job that they cannot see a result of their work. [...] I tried to go on, work, that's how we do it... we prepare a body, takes the body down, and keep working... is just one more who dies..." (Girassol)

The statement above stands out showing the relation between chronicity and unsatisfying results from the professional work and life and death. It is noticeable the frustration before a job that seems to be based in a health care model for acute conditions of illnesses. This model is reproduced in health care schools, establishing policies that are under revision in the present scenario $^{28-30}$.

The evolution of health chronic conditions may trigger to interpretations based on an anticipation of the dying process, identified by the non-visualization of the person in the present time. The view that a child and an adolescent that have a limited life compromises the present and the life perspective concerning its intensity and quality of today:

We see that the children become sick and weaker each day... and you know that one day they will not be here anymore, you look to certain child and you know that it is going to happen, that thing that we already know, right? (Crisântemo)

The interpretation of the living process of children and adolescents with a chronic disease seems to be symbolic marked by the meanings of limitation of projects, lack of perspective and of interaction.

\section{Professional resilience strategies in the living and dying process of pediatrics care}

This item analyzed the meanings identified as strategies to face the limitations generated from the interaction of the professionals with the care provided to patients with chronic diseases. The identification of strategies includes also analyze that such strategies should not be individual bets, but should be ensured through collective management mechanisms of the work process, integrated to the occupation of health. This discussion becomes stronger by Rodrigues ${ }^{5}$, who states that the "death of the other will always trigger my own death; it will witness my precarious nature, it will force me to think about my limits". 
Along the centuries, death has become more understood and experienced in many different ways, according to the social and cultural context of the people. The dying process then gained new meanings and different behaviors were adopted, such as naturalization, social commotion, denying of death and of the individual, public ceremony, ritualism, and death professionalization ${ }^{1,5}$. These behaviors, placed within interaction processes, which has a professional objective, may be interpreted based on resilience.

Death seems to be part of a hospital routine, once it is a place that hosts patients under severe levels of diseases, who need technology-based support, medication therapy, and care. This scenario contradicts with the historical perspective that death used to be an event that could be experienced at home and surrounded by family ${ }^{2,5}$.

The disease acute stages, impossibility to communicate, manifestation of pain and agonizing, often makes the health care professional to question the reason of that patient's existence, and of prolongation of life.

National authors ${ }^{31,32}$ have investigated the contradiction between death at home and death at the hospital. The purpose was to show that the relative silence around death ends up confronting the professionals with feelings related to the death of those they takes care of and to their own death.

The complete training, including sensibility and techniques as ingredients of professional competence, is paramount so the fragility of the patient's human skills does not interfere in the care practice, reducing even more the patient's quality of life.

One of the resilience strategies is found in the search for religious reasons that "justify" the suffering and death situation. The attribution of getting sick, of the suffering, and the vegetative state of the child or adolescent gains different meanings in the common sense: karma due to mistakes made in past lives, divine choice for the parents to take care of a child with special needs, or merely an innate error of nature. The interpretation and attribution of the condition of health, death, suffering, and professional choice as something divine may turn relations and interactions stronger or weaker. If the influence is positive, for example: "God has chosen me", the care is perceived as a divine mission as it is a chance to provide better quality of life to the patients. If it is considered as karma, "he is paying for what he has done in past lives", the professional is judging the patient and it is not up to him to do so, but his care practices may become mechanical with the minimum of involvement. These religious concepts must be considered during the professional training, but they seem to be far from the ideal in the health professionals' training syllabus ${ }^{32}$.

During the moments before death, the professional and personal values are put to the test by the intensity of the suffering and sometimes by the health staff agreement of not investing in that patient anymore. The changes in the pediatrics profile, which today is marked by the epidemiological progress of chronic diseases, compromise the acute cases and trigger ethical dilemmas ${ }^{13}$. Here, "not to invest", means to preserve the patients from suffering, rethinking the therapeutic obstinacy and reconsidering the relevance in performing surgical procedures of technological and ventilation support. Such process is not easy, once it seems to contradict with a training focused on the investment of life at any circumstance. The nursing professional sometimes carries out treatments and provides care to the maintenance of life, even when they are not recommended:

I asked to not let them suffer so close to me. To sedate these children as the suffering is too much for them and for us. They prescribe the medication for pain, but it is a child that stays awake and begs us to not let them die, and there is nothing we can do. In case of children that cannot interact at all, who do not know how to speak, we feel their suffering as we see them crying and we cry as well. But when it is a child that knows how to express, how to talk, how to ask, the suffering is even more. [...] I cannot see this child dying chocked in front of me. (Felícia)

Based on the passage above, it is important to think about a strategy focused on the shared establishment of conducts that favors a dying process without suffering, for the sick patient as well for the professional. It is crucial to have a dialog about the care processes, pain protocols, and patient approach, respecting the group age and their understanding, as well of their families. It is not about abbreviating suffering, but to manage it.

The professional must have some knowledge about the child and adolescent's understanding about death, so the dialog can be consistent with the beliefs, idealizations, and with what they consider to be true concerning death and after death. The process of knowledge and progress of death interpretation during childhood takes place gradually according to the physical, mental, and emotional level. Generally speaking, children's concept about death gets closer to adults' concept at 8 or 9 years old 5 . 
Based on the peculiarity of providing care for these patients, it is important for the management and leaders to provide the staff a support network where they can grow and cope with such situations. Deslandes ${ }^{33}$ points out the dialog deficiency and weak communication process among professionals, users, and managers as factors that often generate physical and mental distress. $\mathrm{He}$ also states that "to humanize the care is to humanize the production of this care" ${ }^{\prime 3}$. The ones interviewed pointed out for the absence of dialog about the conflicting issues that generate suffering. The constitution of a support network may contribute with the individual and collective constitution of resilience, including collaborators and organization.

The institutionalization of the dying one resulted in more deaths taking place at hospitals and the preparation of the body became a task for the nursing staff. Some studies point out that the preparation of the body generates great discomfort for the professionals and that they may experience felling of sadness, depression, and anguish when performing this ritual, and even demonstrating fugue reaction, delegating the task to peers ${ }^{7}$.

I have never made a child packet here, I already said that I won't do it. If I get this close... I leave, cry... (Rosa)

The professional does not get immune to the events. The vulnerability is a constitutive aspect of resilience, once the individual is able to positively respond to the sufferings and is capable to give new meanings to his practices ${ }^{17}$. However, if we understand that there are constitutive practices necessary for certain professional category, as we mention here "to pack up the dead body", the difficulties facing this technique should not be perceived as an individual problem. This deserves to be handled as an object of discussion and thinking by the staff, in such a way to create mechanisms that enable to face this process with collective components rather than individual ones.

The participants highlighted the vulnerability facing the limitation the patient's lives:

And he stopped in front of me [...] and when he died I almost died with him. So they took me out of there because I was colder than the child that was already dead. It was horrible, it was an awful experience. (Felícia)

The ability to do a job, even if emotionally shaken, without missing the objective of the care techniques is allied to the care and emotional support given to the family. For such, keeping a strong staff or specialized support, found in the collective support of discussion and supervision among professionals, may contribute to the creation of resilience collective strategies.

Such analysis does not exclude other possible conception, which is the unbalance facing frequent exposure to situations of extreme:

In February I lost it with a dying child... I performed every care on the child, but crying the whole time... and I would not let anyone help me. [...] I do everything I have to, but I get emotionally tied, I start to shake... so I started to lose it... that is when I really had to leave from there, I had to leave from there, but I was being resistant... [...] I think work has influenced me much about loss... so I could not get attached to many things, I would attach to no one." (Beija-flor)

This statement points out to a behavior of a person that has gone through a lot of suffering and maybe is distressed by the work environment circumstances. When her work in providing care is placed in parallel with matters of risk and vulnerability, it is perceived that the exposure along the years has affected her in such a way that, although she has characteristics quite related to resilience, the continuous stressful situation undermined her persistence to perform care actions. Thus, the reduction to an individualized pole that generates loneliness, increasing distress and affective failure along the time.

Some behaviors of the professional, such as despair and crying, show the intensity of the suffering originated in the care process and that were experienced as a result of the self-responsibility, with no collective support:

And he died two weeks later. And I cried a lot, really a lot... I imagined the pain he felt... And when I went to prepare his body, I could not do it... I had to call my colleague, as I cried I lot when I had to prepare the body. And when I took to the mother so she could see him, it was already downstairs, right? [...] So, I did not seek for any help, I suffered quietly, I cried and cried... (Cisne)

Schmidt et al..$^{34}$ discuss on the importance to extend emotional support to the professional staff of the institution, once the staff members get emotionally distressed in situations of death and terminal illness of those hospitalized. The testimonies of the participants make clear the need for attention concerning their emotional needs, of a professional that helps them to understand the extreme situations in their care practices ${ }^{34}$.

I stayed there ventilating the child for almost half hour and seeing her dying and I couldn't do anything, pretending to be strong, to be a hero... 
That took too hard on me. [...] And as I said, they are chronicle ill children who are postponing the inevitable, which is their death. So, that is what strikes me most, to lose a child, to know she was going to die. Then I had to take her, make the packet, go downstairs and show to the mother. I think there should be a specific person to prepare the body. Why it has to be me, who was taking care of her while she was alive? (Antúrio)

The encounter with the instabilities stands out and triggers a technical fugue reaction in the professional. The manner that the process of living, getting sick and dying is described triggers a relation in which the body becomes an object, although it isn't. The presentation of the dead body to the mother is perceived as an episode with no reference of bond and affection that justifies that that professional must do it.

In the scenario studied, there is no work developed for the care staff. Many individuals talk about this institutional deficiency, stating they think that is necessary to "take care of those who take care". The promotion of resilience for the professionals in this field must strive for the collective construction, dialoging support, technical training, qualified support network, and personal path in the construction of the career and of work choices.

\section{Final considerations}

Health professionals that experiences the living and dying process of children and adolescents under limitation of life, carry marks with them. These experiences are the path to build resilience; it is the moment that the individual goes through an impact, gets hit by it, transforms it, and faces it. Still, the professional manages to cope and gets stronger, acquiring professional and affective skills for his or her life. Death and the manner to experience it during the care provided must be acknowledged as part of the health care work process. The work provided to children and adolescents with chronic diseases in the end of life must acknowledge: 1) the fact that death threatens cultural representations about the strength, joy and future project that are part of such life cycles; 2) the professional training in health areas still gives little attention to sociological and anthropological, historical, and philosophical literature; 3 ) the naturalization of the idea that suffering and death are part of the work dynam- ics in the health care area contributes to fade out the concepts developed along the time in providing care to situations involving limitation of life; 4) the need to value, when analyzing resilience, the collective and socially and culturally aspects shared from the experience to work in environments of high emotional and physical distress. This study highlights these pediatrics wards, where the chronic disease not only imposes limits to the development of life beyond the hospital but that often brings early death as the outcome. The institutions must build bonds of trust and groups must become teams, providing support for those members who might find themselves fragile along the way.

This study verified that health care professionals apply the following resilience strategies: during the living and dying process resulting from the chronic disease, they believe in their skills as individuals, combining techniques and affection; they strive to search for religious reasons; they avoid suffering for the one dying during the dying process; they exchange tasks between the team.

These strategies do not find collective answers, organized within the work processes, in the field investigated. The individualization of the suffering leads to the search for lonely way outs, which many times are reduced to outbursts and sporadic talking, based on friendships. This study based on the ethical-political imperative that if the work was accountable for the suffering and distress, the individual deserves attention from the management mechanisms. This conclusion is aligned with the principles of the National Policy for Humanization of Attention and Management and with themes that mobilize workers and make them understand about their importance. More important than raising the topic of humanization in health care, which is legitimate and relevant, is to understand what motivates, hinders, compose alliances or fade out bonds in the micro environments, where some attitudes and behaviors may even by hidden, but are revealed in the fragility of the practices and in the influence of this professional-related suffering on the personal lives of the individuals. The themes on death, pain, and illnesses in children and adolescents, just to quote some examples cross-sectional to this article, may seem to dialog with the promotion of resilience at work; thus, dialoging with the qualification of attention and management in the health care environment. 


\section{Collaborators}

RA Santos conducted the field work and wrote the article, based on his master's thesis. MCN Moreira advised on the thesis and on the elaboration of the article.

\section{References}

1. Menezes RA. Em busca da boa morte: uma antropologia dos cuidados paliativos. Rio de Janeiro: Garamond, Fiocruz; 2004

2. Ariès P. História da morte no ocidente. Rio de Janeiro: Ediouro; 2003.

3. Bronfman M. Como se vive se muere: família, redes sociales y muerte infantil. Buenos Aires: Lugar Editorial; 2001.

4. Elias NA. Solidão dos moribundos seguido de envelhecer e morrer. Rio de Janeiro: Jorge Zahar; 2001.

5. Rodrigues JC. Tabu da morte. Rio de Janeiro: Achiamé; 1983.

6. Borges MS, Mendes N. Representações de profissionais de saúde sobre a morte e o processo de morrer. Rev bras Enferm 2012; 65(2):324-331.

7. Mota MS, Gomes GC, Coelho MF, Filho WDL, Sousa LD. Reações e sentimentos de profissionais da enfermagem frente à morte dos pacientes sob seus cuidados. Rev Gaúcha Enferm 2011; 32(1):129-135.

8. Menezes RA. Profissionais de saúde e a morte: emoções e forma de gestão. Teoria e sociedade 2005; 13(1):200225.

9. Santos RA. A construção da resiliência pelos trabalhadores de enfermagem na atenção a crianças e adolescentes cronicamente adoecidos [dissertação]. Rio de Janeiro: Fiocruz; 2011

10. Tavares J. Resiliência e educação. $3^{\circ}$ ed. São Paulo: Cortez; 2002.

11. Rocca L SML. Resiliência: uma perspectiva de esperança na superação das adversidades. In: Hoch LC, Rocca L SM, organizadores. Sofrimento, resiliência e fé: implicações para as relações de cuidado. São Leopoldo: Sinodal; 2011.p. 9-27.

12. Cyrulnik B. El amor que nos cura. Barcelona: Gedisa; 2005.

13. Costa MTF, Gomes MA, Pinto M. Dependência crônica de ventilação pulmonar mecânica na assistência pediátrica: um debate necessário para o SUS. Cien Saude Colet 2011; 16(10):4147-4159.

14. Moreira MEL, Goldani MZ. A criança é o pai do homem: novos desafios para a área de saúde da criança. Cien Saude Colet 2010; 15(2):321-327.

15. Lyra GV, Nations MK, Catrib AMF. Cronicidade e cuidados de saúde: o que a antropologia da saúde tem a nos ensinar. Texto Contexto Enferm 2004; 13(1):147-55.

16. Moreira MCN, Souza WS. A temática da humanização na saúde: alguns apontamentos para debate. Interface (Botucatu) 2008; 12(25):327-338

17. Assis SG, Avanci JQ, Pesce RP, Deslandes SF. Superação de dificuldades na infância e adolescência: Conversando com profissionais de saúde sobre resiliência e promoção da saúde. Rio de Janeiro: Fiocruz; 2006.

18. Fontanella BJB, Luchesi BM, Saidee MGB, Ricas J, Turato ER, Melo DG. Amostragem em pesquisas qualitativas: proposta de procedimentos para constatar saturação teórica. Cad Saude Publica 2011; 27(2):389-394. 
19. Minayo MCS. O desafio do conhecimento: Pesquisa qualitativa em saúde. $11^{\mathrm{a}}$ ed. São Paulo: Hucitec; 2008.

20. Nunes ED. Goffman: Contribuições para a Sociologia da Saúde. Physis 2009; 19(1):173-187.

21. Moreira MCN, Souza WS. A microssociologia de Erving Goffman e a análise relacional: um diálogo metodológico pela perspectiva das redes sociais na área de saúde. Teoria \& Sociedade 2002; 9(9):38-61.

22. Goffman, E. Estigma. Petrópolis: Vozes; 1988.

23. Winnicott DW. Conversando com os pais. São Paulo: Martins Fontes; 1999.

24. Pitta A. Hospital: dor e morte como ofício. São Paulo: Hucitec; 2003.

25. Pinto LF. As crianças do Vale da Morte: Reflexões sobre a criança terminal. Jornal de Pediatria 1996; 72(5):287294.

26. Palú LA, Labrocini LM, Albini L. A morte no cotidiano dos profissionais de enfermagem de uma unidade de terapia intensiva. Cogitare Enferm 2004; 9(1):33-41.

27. Santos JL, Bueno SM. Educação para a morte a docentes e discentes de enfermagem: revisão documental da literatura científica. Rev Esc Enferm USP 2011; 45(1):272-276.

28. Organização Mundial de Saúde (OMS). Cuidados inovadores para condições crônicas: componentes estruturais de ação. Brasília: OMS; 2003.

29. Organização Pan-americana de Saúde (OPAS). As redes de atenção à saúde. 2a ed. Brasília: OPAS; 2011.

30. Araújo PVR, Vieira MJ. A questão da morte e do morrer. Rev Bras Enferm 2004; 57(3):361-363.

31. Oliveira MAP, Ogasawara M. Uma contribuição para uma postura humana em situação que se relaciona com a morte. Rev Esc Enf USP 1992; 26(3):365-378.

32. Bernieri J, Hirdes A. O preparo dos acadêmicos de enfermagem brasileiros para vivenciarem o processo morte-morrer. Texto Contexto Enferm 2007; 16(1):8996.

33. Deslandes SF. Análise do discurso oifical sobre a humanização da assistência hospitalar. Cien Saude Colet 2004; 9(1):7-14.

34. Schmidt B, Gabarra LM, Gonçalves JR. Intervenção psicológica em terminalidade e morte: relato de experiência. Paidéia 2011; 21(50):423-430.

Article submitted on 05/10/2013

Approved 06/11/2013

Final version submitted on 08/11/2013 